\title{
Antifungal Activity and the Mechanism of Ozone Against Spoilage Molds, Such as Gibberella Intermedia and Aspergillus Ochraceus Isolated From Freshly-Peeled Garlic
}

\author{
Yuan Ma \\ Xihua University \\ Ping Yang \\ Xihua University \\ Xiaocui Liu \\ Xihua University \\ Lin Cao \\ Xihua University \\ Yage Xing ( $\nabla$ xingyage1@163.com ) \\ Xihua University \\ Jia Tan \\ Xihua University \\ Qinglian Xu \\ Xihua University \\ Xiaomin Wang \\ Xihua University \\ Yuru Shui \\ Xihua University \\ Xuanlin Li \\ Xihua University \\ Lin Xu \\ Xihua University \\ Shuang Yang \\ Xihua University \\ Xiufang Bi \\ Xihua University \\ Hua Yang \\ Xihua University
}

Original article 
Keywords: Freshly-peeled garlic, Ozone, Antibacterial Activities in Vivo, Transcription group sequencing Posted Date: July 14th, 2021

DOI: https://doi.org/10.21203/rs.3.rs-678711/v1

License: (9) This work is licensed under a Creative Commons Attribution 4.0 International License. Read Full License 


\section{Abstract}

The antibacterial effect and mechanism of ozone $\left(\mathrm{O}_{3}\right)$ treatment on freshly-peeled garlic inoculated with Gibberella intermedia (G. intermedia) and Aspergillus ochraceus (A. ochraceus) in different conditions were studied in vivo. The results showed that the specific $\mathrm{O}_{3}$ concentration, treatment time, and humidity significantly affected the garlic's indexes. The optimal treatment conditions of garlic inoculated with both molds were 6 ppm, 15 min, and 90\%, respectively. After treatment with those conditions, the incidence etc of garlic were significantly reduced during storage. Differential analysis was performed for the RNA-sequencing and gene expression of the molds subjected to $\mathrm{O}_{3}$ treatment, as well as the samples that were not. The results showed that $\mathrm{O}_{3}$ treatment inhibited the growth of $G$. intermedia and $A$. ochraceus. Consequently, 2754 and 2378 differentially expressed genes, 1456 and 1591 up-regulated genes, and 1298 and 787 downregulated genes were screened, respectively, for these molds, affecting the catalytic activity and various other pathways.

\section{Introduction}

Garlic (Allium sativum L.) is a herbaceous plant containing proteins, fats, minerals, polysaccharides, flavonoids, and specific allicin and phenolic components, as well as sulfur-containing compounds (Bozin et al., 2008;Natália et al., 2016). Garlic has been used as a food flavoring for thousands of years due to its moderately spicy flavor and high levels of organosulfur compounds, such as allicin (Wu et al., 2016). It has historically been used to treat aches and pains, leprosy, deafness, severe diarrhea, constipation, parasitic infections, and asthma, as well as to lower fever, fight infections, and relieve stomachaches (Rana et al., 2011). In their current fast-paced lives, people require convenience when it comes to fruit and vegetables. Consumers increasingly favor freshly-peeled garlic because of exactly this reason. However, when the protective epidermis is removed, freshly-peeled garlic cloves have a shorter shelf life due to enzymatic/nonenzymatic browning, sprouting, moisture loss, microbial spoilage, and surface discoloration (Singh et al., 2019), and is prone to decay, which causes it to lose its commercial value. Previous research isolated and identified the main mold strains that cause the spoilage of freshly-peeled garlic as $G$. intermedia and $A$. ochraceus. Gibberellin and Aspergillus produced by G. intermedia and $A$. ochraceus respectively, they all causes rapid germination and excessive growth of freshly-peeled garlic, which leads it to rapid consumption of nutrients, color change, mildew. Consequently, it is important to find suitable antimicrobial and preservation agents to improve the quality of freshly-peeled garlic and control the growth of $G$. intermedia and $A$. ochraceus. Many traditional chemical preservatives are limited because of increasing health risk concerns. This creates a need for developing an antimicrobial agent with no residue and a strong bactericidal effect to inhibit the activity of $G$. intermedia and $A$. ochraceus, while ensuring the storage quality of freshly-peeled garlic.

$\mathrm{O}_{3}$, as one of the allotropic forms of oxygen, is a powerful antimicrobial agent because of its potential oxidizing capacity (Mylona., 2014). In 1997, $0_{3}$ was granted Generally Recognized As Safe (GRAS) status (US-FDA, 1997) and had since received full US-FDA approval as a direct contact food sanitizing agent (USFDA, 2001) (Tzortzakis., 2006). Recently, $\mathrm{O}_{3}$ has been gradually applied in the food industry because of its 
many advantages, such as strong oxidation, while decomposing to oxygen without leaving a trace in the treated substrates (Andrew et al., 2015; Qi et al., 2016). Nowadays, $\mathrm{O}_{3}$ is attracting increasing attention as a potential method for treating fruits ( Sarig et al., 1996), vegetables, and grain, while reducing mold contamination or mycotoxins in various food products (Freitas-Silva, and Venancio, 2010) (Ong M.K. and Ali, 2015; Karaca, Velioglu, and Nas, 2010) Furthermore, the bactericidal effects of $\mathrm{O}_{3}$ on a wide variety of microorganisms have been confirmed, which includes Gram-positive and Gram-negative bacteria, as well as bacterial spores (Brodowska, Nowak, and Smigielski, 2018). Franco C (2008) reported that $\mathrm{O}_{3}$ could effectively degrade patulin, both in aqueous solutions and in diluted apple juice. Cho et al. (2009) reported that treating fresh vegetable juice with $\mathrm{O}_{3}$ decreased the microbial numbers, while the treated sample's chemical characteristics displayed no differences compared with the control. Additionally, the antimicrobial activity of $\mathrm{O}_{3}$ is obtained directly via the progressive oxidation of vital cell components leading to the inhibition of microbial growth (M.E.Parish et al., 2003). Therefore, the proliferation of $G$. intermedia and $A$. ochraceus in freshly-peeled garlic can be inhibited by $\mathrm{O}_{3}$, while improving the methods used for the storage and preservation of freshly-peeled garlic.

\section{Materials And Methods 2.1. Materials}

The garlic was purchased in Bubugao supermarket, Hongguang Town, Pidu District, Chengdu. Peeled garlic was left at room temperature until moldy.

The G. intermedia and A. ochraceus was obtained via the separation and purification of the moldy garlic.

G.intermedia (SICC3.976) and A. ochraceus (SICC3.975), which were stored in the Southwest Center of Industrial Culture Collection in China), and isolated from spoiled and moldy freshly-peeled garlic, were used throughout the study. The isolate was maintained on potato dextrose agar (PDA, Beijing Aobox Biotechnology Co., Ltd. (Beijing, China), at $4^{\circ} \mathrm{C}$ until needed.

G. intermedia and A. ochraceus samples were placed on PDA and activated according to the method reported by loannis et al. (2010), and Pedroso et al. (2014) with some modifications. The samples were activated in potato dextrose broth (PDB, Beijing Aobox Biotechnology Co., Ltd. (Beijing, China) in a shaker at $28^{\circ} \mathrm{C}$ for $72 \mathrm{~h}$. Then, $G$. intermedia was cultured on PDA at $28^{\circ} \mathrm{C}$ for $72 \mathrm{~h}$ in an incubator (SKP-02,Huangshi Hengfeng Medical Instruments Co., Ltd.). Finally, the G. intermedia and $A$. ochraceus conidia were collected from the PDA by adding $10 \mathrm{~mL}$ sterile water to the Petri dish, adjusting the conidial suspension to a concentration of $10^{6} \mathrm{CFU} / \mathrm{mL}$.

\section{2. $\mathrm{O}_{3}$ exposure}

$\mathrm{O}_{3}$ was produced using an $\mathrm{O}_{3}$ generator (YS-MJCB-S17, Hangzhou Yishi Technology Co., Ltd.) that utilized an oxygen flow of $2 \mathrm{~L} \cdot \mathrm{min}^{-1}$ from the Mark 5 Plus 95 Concentrator Oxygen Concentrator (Nidek Medical Products, Birmingham, AL, EUA). 


\subsection{Live inoculation}

Freshly-peeled garlic that was uniform in size and free of pests and diseases was selected, washed with tap water, and dried. The samples were divided into four groups, each weighing $2 \mathrm{~kg}$. The samples' surfaces were sterilized with $75 \%$ alcohol and placed on standby after ultraviolet irradiation for 30 min. A wound with a $2 \mathrm{~mm}$ diameter and a depth of $5 \mathrm{~mm}$ was pricked symmetrically in the middle of each piece of garlic using a sterile inoculating needle. After $30 \mathrm{~min}, 5 \mu \mathrm{L}$ of scab and $A$. ochraceus and $G$. intermedia suspension with spore concentration of $1 \times 10^{6} \mathrm{CFU} / \mathrm{mL}$ were inoculated respectively in each group of garlic wounds. Each group was divided into different fresh-keeping boxes sterilized with $\mathrm{O}_{3}$. Freshly-peeled garlic inoculated with different molds was treated with different $\mathrm{O}_{3}$ concentrations ( 1 ppm, 2 ppm, 3 ppm, 4 ppm, 5 ppm, and 6 ppm), times ( $3 \mathrm{~min}, 6 \mathrm{~min}, 9 \mathrm{~min}, 12 \mathrm{~min}, 15 \mathrm{~min}$, and $18 \mathrm{~min}$ ), and humidity (85\%, 90\%, and 95\%). The untreated samples were considered the control group. The total number of colonies (TNC), the total number of mold and yeast (TNMY), incidence, lesion diameter, and lesion depth of each group of freshly-peeled garlic were measured every other day .

\subsection{The determination of the TNC, TNMY, incidence, diameter, and lesion depth}

The TNC and TNMY were quantified according to the method described by Akshata et al. (2019). The estimation of TNC was performed on plate count agar, while the TNMY was determined using PDA via the spread plate method. The colony-forming units (CFU) were counted after incubation at $37^{\circ} \mathrm{C}$ for $24 \mathrm{~h}$, while the molds and yeasts were identified after incubation at $30^{\circ} \mathrm{C}$ for $48 \mathrm{~h}$.

The incidence and weight of the garlic were counted and weighed the next day. The incidence was calculated using the following formula:

Incidence $(\%)=($ weight of diseased garlic $(\mathrm{g})) /($ weight of total inoculated garlic $(\mathrm{g})) \times 100 \%$

The lesion diameter was measured the next day. Here, ten garlic samples were used for each measurement. Calculations were performed using vernier calipers and the cross method, while the garlic's average lesion diameter was also taken.

The lesion depth was measured the next day. Here, 10 garlic samples were used for each measurement and cut along the wound direction. Calculations were performed using vernier calipers, and the average value was taken as the final result.

\subsection{Analysis of the differentially expressed genes}

Here, $20 \mathrm{~mL}$ PDB containing $G$. intermedia and A. ochraceus conidia was placed on blank Petri dishes (5 dishes per treatment). The dishes' lids were removed to allow the airflow and placed in treatment rooms $\left(20^{\circ} \mathrm{C}\right.$, and the room humidity was $\left.95 \%\right)$, where they were exposed to continuous $\mathrm{O}_{3}$ at concentrations of 0 ppm and $6 \mathrm{ppm}$ for $20 \mathrm{~min}$. At the end of each exposure, the PDB medium containing the $G$. intermedia and A. ochraceus conidia was transferred to a sterile centrifugal tube, after which it was placed in a shaker at $28^{\circ} \mathrm{C}$ for $72 \mathrm{~h}$. At the end of incubation, the mycelium of $\mathrm{G}$. intermedia and $A$. ochraceus was collected for $\mathrm{O}_{3}$ 
treatment, and non- $\mathrm{O}_{3}$ treatment after centrifugation at $4^{\circ} \mathrm{C}$ for $15 \mathrm{~min}$ and repeatedly washed with phosphate buffer saline (PBS).

The total RNA was extracted using an RNA Extraction Kit (Tiangen Biotech CO., LTD., Peking, China) according to the manufacturer's instructions and the method reported bywith some modifications. The purity and integrity of the RNA samples were detected using the NanoDrop and Agilent 2100 methods after removing residual DNA. After the sample passed the test, the PCR product was heat-denatured into a single strand, and a single-stranded cyclic DNA library was obtained via the cyclization of the single-stranded DNA with a bridge primer. Finally, the library was sequenced using the BGIS EQ-500 Sequencing Platform.

Data from the BGIS EQ-500 Sequencing Platform are known as raw reads or raw data, while it is called clean reads after filtration. The de novo assembly of the clean reads was performed using Trinity, after which the assembled transcripts were clustered for redundancy using TGICL. These sequences were defined as UniGenes. Subsequently, the assembled UniGenes were annotated by seven kinds of protein databases, including the Kyoto Encyclopedia of Genes and Genomes (KEGG) database, the Gene Ontology (GO) database, the NCBI nonredundant protein (NR) database, the Nonredundant nucleic acid (NT) database, the Swiss-Prot protein database, the Pfam database and the clusters of Karyotic Orthologous Groups (KOG) database.

Using NR annotation, the Blast2GO program was used to obtain the $\mathrm{GO}$ annotations for the UniGenes. Furthermore, the $\log _{2}$ fold change $\varangle>4$ and $p<0.001$ were used as the standard for evaluation and screening to select the differentially expressed genes of $G$. intermedia and $A$. ochraceus. To compare the differences in gene expression, the differentially expressed genes were subjected to $\mathrm{GO}$ enrichment analysis, and those associated with the $\mathrm{O}_{3}$ inhibition of $G$. intermedia growth were identified.

\subsection{Statistical analysis}

The tests in this investigation were carried out in triplicate. The test results were analyzed using SPSS 20.0 software (SPSS Inc.) and expressed as mean \pm standard deviation. The one-way analysis of variance procedure, followed by the Student-Newman-Keuls test, was used to determine the significant difference ( $p$ $<0.05)$ between the treatment means.

\section{Results}

\subsection{The effect of different $\mathrm{O}_{3}$ treatment conditions on the TNC in freshly-peeled garlic}

As shown in Fig. 1(A), during storage, the TNC on the surface of fresh garlic inoculated with G. intermedia and $A$. ochraceus at different $\mathrm{O}_{3}$ concentrations was significantly lower than that of the blank group $(P<$ 0.05). Cunkun Chen et al. (2020) reported similar findings that 03 treatment can inhibit the bacteria and fungi that lead to the corruption of Hami melon by postharvest pathogens at appropriate doses. With an increase in storage time, the TNC on the surface of fresh garlic in each experimental group increased. For the fresh garlic inoculated with $G$. intermedia, the TNC increased with an increase in the $\mathrm{O}_{3}$ concentration, while $6 \mathrm{ppm}$ was the optimal $\mathrm{O}_{3}$ concentration level. For freshly-peeled garlic inoculated with $A$. ochraceus, the 
TNC displayed a lower level of decline when the $\mathrm{O}_{3}$ concentration increased from 1 ppm to 3 ppm, while the decrease was higher when the $\mathrm{O}_{3}$ concentration changed from $4 \mathrm{ppm}$ to $6 \mathrm{ppm}$. When the garlic was stored for $10 \mathrm{~d}$, no significant difference was evident between the freshly-peeled garlic treated with 1 ppm $\mathrm{O}_{3}$ and the blank group $(P>0.05)$. Therefore, it can be concluded that an $\mathrm{O}_{3}$ treatment concentration of 6 ppm was optimal in the freshly-peeled garlic inoculated with $A$. ochraceus.

Fig. 1(B) shows that an extended storage time increased the TNC at the same $\mathrm{O}_{3}$ treatment time. After inoculation with $\mathrm{G}$. intermedia, the TNC on the fresh garlic's surface was low after $\mathrm{O}_{3}$ treatment for 15 min, while the germicidal effect had improved. When fresh garlic inoculated with $A$. ochraceus was stored for 10 $\mathrm{d}$, the difference between $\mathrm{O}_{3}$ treatment and blank groups was significant $(P<0.05)$, while the optimal $\mathrm{O}_{3}$ treatment time was $15 \mathrm{~min}$. These results are similar to those revealed by Showkat et al. (2019), who studied the effect of $\mathrm{O}_{3}$ treatment on bacteria in fruit. After a certain period of $\mathrm{O}_{3}$ treatment, the number of kiwifruit colonies decreased and prevented bacterial growth.

Fig. 1(C) shows that under the same $\mathrm{O}_{3}$ treatment humidity, the TNC on the surface increased with an extension in storage time. A significant difference was evident between the $\mathrm{O}_{3}$ treatment group with $85 \%$ humidity and the treatment group with $90 \%$ humidity $(P<0.05)$. During the $10 \mathrm{~d}$ of storage, the TNC on the fresh garlic's surface inoculated with the types of bacteria exhibited no significant change after treatment with $\mathrm{O}_{3}$ gas at $90 \%$ and $95 \%$ humidity, respectively. After storage for $10 \mathrm{~d}$, the TNC on the surface of freshlypeeled garlic inoculated with $G$. intermedia and $A$. ochraceus was $3.37 \mathrm{lg} \mathrm{CFU} / \mathrm{g}$ and $3.92 \mathrm{lg} \mathrm{CFU} / \mathrm{g}$, respectively. Therefore, when considering lower costs, the optimal Ig CFU/g treatment humidity was $90 \%$.

\subsection{The effect of different $\mathrm{O}_{3}$ treatment conditions on the TNMY in freshly-peeled garlic}

As shown in Fig. 2(A), the TNMY in freshly-peeled garlic inoculated with G. intermedia and $A$. ochraceus at different $\mathrm{O}_{3}$ concentrations changed with storage time. At the same storage time, the TNMY decreased with an increase in the $\mathrm{O}_{3}$ concentration. After the same concentration of $\mathrm{O}_{3}$ treatment, with the increase of storage time, the TNMY increased. A significant difference $(P<0.05)$ was evident between the $\mathrm{O}_{3}$ treatment groups and the blank group in the fresh garlic inoculated with $G$. intermedia. A similar phenomenon was apparent between the groups subjected to different $\mathrm{O}_{3}$ concentrations. The results showed that 6 ppm was the better $\mathrm{O}_{3}$ concentration. No significant mold and yeast levels were detected in the $1 \mathrm{ppm}, 2 \mathrm{ppm}$, and blank groups of the fresh garlic inoculated with $A$. ochraceus. When the $\mathrm{O}_{3}$ concentration increased to 3 ppm, the TNMY decreased as the treatment concentration continued to increase. Moreover, the TNMY in the fresh garlic was the lowest after treatment with $6 \mathrm{ppm} \mathrm{O}_{3}$.

As shown in Fig. 2(B), the TNMY on the surface of the fresh garlic decreased with an increase in the treatment time and storage period at the same storage time. When the $\mathrm{O}_{3}$ treatment time increased from 15 min to $18 \mathrm{~min}$, no significant difference was evident in the TNMY $(P>0.05)$ levels, but it was significantly lower than in the blank group and the previous experimental group $(P<0.05)$, while the better $\mathrm{O}_{3}$ treatment time was $15 \mathrm{~min}$. P. Sarig et al. (1996) found that when berries were exposed to $\mathrm{O}_{3}$ for $20 \mathrm{~min}$, the number of CFU of the fungi, yeast, and bacteria that naturally exist on the surface of the fruit was significantly reduced. 
$\mathrm{O}_{3}$ treatment substantially reduced the level of decay caused by fungi after cold storage and prolonged the quality assurance period of the berries. This is consistent with the results indicating that the quantity of mold and yeast decreased after the fresh garlic was treated with $\mathrm{O}_{3}$ for a particular time at a specific concentration.

Fig. 2(C) shows that after $\mathrm{O}_{3}$ treatment at 90\% and 95\% humidity, respectively, the TNMY in the freshlypeeled garlic inoculated with $G$. intermedia and $A$. ochraceus was always lower than in the treatment group subjected to $85 \%$ humidity. After $10 \mathrm{~d}$ of storage, the TNMY in the $\mathrm{O}_{3}$ treatment group at $90 \%$ humidity was $3.55 \mathrm{lg}$ CFU / g and $3.48 \mathrm{lg}$ CFU / g, respectively, which was considerably lower than in the treatment group exposed to $85 \%$ humidity.

\subsection{The effect of different $\mathrm{O}_{3}$ treatment conditions on the incidence of freshly-peeled garlic}

As shown in Fig. 3(A), $\mathrm{O}_{3}$ treatment significantly inhibited the incidence of freshly-peeled garlic inoculated with $G$. intermedia and $A$. ochraceus. After inoculation with $G$. intermedia, the garlic incidence decreased in conjunction with an increase in the $\mathrm{O}_{3}$ concentration at the same storage time. After $10 \mathrm{~d}$ of storage, the fresh garlic incidence in the 6 ppm treatment group was the lowest at only $44.85 \%$, which was substantially lower than in the blank group (98.68\%). Furthermore, when the fresh garlic was inoculated with $A$. ochraceus, the differences between the blank, the $1 \mathrm{ppm}$, and the $2 \mathrm{ppm} \mathrm{O}_{3}$ treatment groups were small, and the total incidence was high at the same storage time. Additionally, when the $\mathrm{O}_{3}$ concentration increased to $6 \mathrm{ppm}$, the fresh garlic incidence was the lowest of all the storage times, while the germicidal effect was the best.

After $\mathrm{O}_{3}$ treatment at different times, the incidence of the freshly-peeled garlic inoculated with $G$. intermedia and $A$. ochraceus during storage is shown in Fig. $3(\mathrm{~B}(\mathrm{a}))$ and Fig. $3(\mathrm{~B}(\mathrm{~b}))$, respectively. With an extended storage time, the incidence of the garlic increased gradually. After $10 \mathrm{~d}$ of storage, the incidence of the blank group reached $100 \%$. With an increase in the treatment time, the garlic incidence decreased slowly at the same storage time. After $15 \mathrm{~min}$ of $\mathrm{O}_{3}$ treatment, the incidence of the fresh garlic inoculated with the two types of mold remained low. When the treatment time continued to increase, no significant reduction was evident. After $10 \mathrm{~d}$ of storage, the incidence was $49.75 \%$ and $44.55 \%$, respectively.

Fig. 3(C) indicated that during the entire storage period, the curve of the $\mathrm{O}_{3}$ treatment group at $85 \%$ humidity exceeded the curve of the $\mathrm{O}_{3}$ treatment groups at $90 \%$ and $95 \%$ humidity, and the incidence of fresh garlic treated with $90 \%$ and $95 \% \mathrm{O}_{3}$ was significantly lower than that of the $\mathrm{O}_{3}$ treatment group at $85 \%$ humidity. At the end of the storage period, the freshly-peeled garlic incidence exposed to $90 \%$ humidity was $49.75 \%$ and $44.55 \%$, respectively. From the perspective of saving resources, $90 \% \mathrm{O}_{3}$ humidity was selected as appropriate, which was consistent with the results suggesting that $\mathrm{O}_{3}$ could reduce the incidence rate of papaya and red peppers, according to Marcin (2016).

\subsection{The effect of different $\mathrm{O}_{3}$ treatment conditions on the lesion diameter of freshly-peeled garlic}

Fig. 4(A) shows that extended storage time increased the lesion diameter of freshly-peeled garlic as the $\mathrm{O}_{3}$ concentration became higher, while the lesion diameter of the blank group always remained at the maximum 
level. After $\mathrm{O}_{3}$ treatment at different concentrations, the $6 \mathrm{ppm}$ group displayed the best bacteriostatic effect and the smallest lesion diameter during storage. After $10 \mathrm{~d}$ of storage, the lesion diameter of the freshlypeeled garlic inoculated with $G$. intermedia and $A$. ochraceus was $3.07 \mathrm{~mm}$ and $2.67 \mathrm{~mm}$, respectively, which was substantially lower than in the blank group (5.53 $\mathrm{mm}$ and $5.90 \mathrm{~mm}$ respectively).

Fig. 4(B) shows that at the same storage time, the lesion diameter of the freshly-peeled garlic inoculated with $G$. intermedia and $A$. ochraceus gradually decreased with an increase in treatment time. After $10 \mathrm{~d}$ of storage, little change occurred in the lesion diameter after $15 \mathrm{~min}$ of $\mathrm{O}_{3}$ treatment $(3.37 \mathrm{~mm}$ and $3.27 \mathrm{~mm}$, respectively), and $18 \mathrm{~min}$ of $\mathrm{O}_{3}$ treatment $\left(3.28 \mathrm{~mm}\right.$ and $3.14 \mathrm{~mm}$ respectively). Therefore, $\mathrm{O}_{3}$ treatment for 15 min achieved better control effect on the disease spot diameter.

Fig. 4(C) shows the changes in the lesion diameter of freshly-peeled garlic inoculated with Pythium after $\mathrm{O}_{3}$ treatment at different humidity levels. The lesion diameter increased with the storage time. From the beginning to the second day of storage, the lesion diameter increased sharply, and then rose gradually over time. At the same storage time point, the change in the lesion diameter with $\mathrm{O}_{3}$ humidity was small, but the lesion diameter of the fresh garlic treated with $\mathrm{O}_{3}$ at $90 \%$ and $95 \%$ humidity was still slightly lower than that of the $\mathrm{O}_{3}$ treatment group at $85 \%$ humidity. Based on these indicators' experimental results, $90 \%$ humidity was selected as the appropriate $\mathrm{O}_{3}$ treatment level.

\subsection{The effect of different $\mathrm{O}_{3}$ treatment conditions on the lesion depth of freshly-peeled garlic}

Fig. 5(A) indicates that for the freshly-peeled garlic inoculated with $G$. intermedia, at the same storage time point, the change of the lesion depth changes slowly with the increase of concentration, but in general, the total treatment value of lesion depth of freshly-peeled garlic treated with $6 \mathrm{ppm}_{3}$ was smaller. For fresh garlic inoculated with $A$. ochraceus, when the $\mathrm{O}_{3}$ concentration was lower than $4 \mathrm{ppm}$, the lesion depth change with the concentration was smaller under the same storage time. When the $\mathrm{O}_{3}$ concentration increased from 3 ppm to 4 ppm, the fresh garlic's lesion depth exhibited a visible change. When the $\mathrm{O}_{3}$ concentration increased to $6 \mathrm{ppm}$, the lesion depth was the smallest.

The change in lesion depth in conjunction with storage time is shown in Fig. 5(B) after treatment with the same $\mathrm{O}_{3}$ concentration at different times. It indicated that the lesion depth of the freshly-peeled garlic increased with extended storage time. Furthermore, it demonstrated that the lesion depth exposed to $\mathrm{O}_{3}$ treatment for 3 min coincided with that of the blank group, with no significant difference. A further increase in treatment time significantly affected the inhibition of lesion depth. Regarding the freshly-peeled garlic inoculated with $A$. ochraceus, when the $\mathrm{O}_{3}$ treatment time increased from $15 \mathrm{~min}$ to $18 \mathrm{~min}$, the depth of the garlic spots decreased slightly. Therefore, an $\mathrm{O}_{3}$ treatment time of 15 min improved the inhibition. Regarding the fresh garlic inoculated with $G$. intermedia, no significant difference was evident between the three treatment groups (12 min, $15 \mathrm{~min}$, and $18 \mathrm{~min}$ ) in terms of the degree of curve coincidence. The curve basically coincided, and the lesion depth always remained low. To save costs and protect the environment, the 12 min $\mathrm{O}_{3}$ treatment time was chosen. 
Fig. 5(C) shows that from the beginning of storage and at the same storage time point, when the humidity increased from $85 \%$ to $90 \%$, the disease spot depth of the freshly-peeled garlic inoculated with $G$. intermedia decreased significantly. When the humidity continued to increase to $95 \%$, the disease spot depth remained unchanged. Regarding the freshly-peeled garlic inoculated with A. ochraceus when the storage time was less than $4 \mathrm{~d}$, no significant differences were evident between the three $\mathrm{O}_{3}$ treatments. From the 6 th day of storage, the lesion depth of the freshly-peeled garlic treated with $85 \%$ humidity was significantly higher than that of freshly-peeled garlic exposed to $90 \%$ and $95 \%$ humidity. Based on these results, $90 \%$ humidity was selected as optimal during the $\mathrm{O}_{3}$ treatment of $G$. intermedia.

\subsection{Analysis of the transcriptome differences in the putrefactive fungi in fresh garlic}

\subsubsection{Sample RNA test results of G. intermedia and A. ochraceus}

The RNA of the $\mathrm{O}_{3}$ treated, and untreated Gibberella and ochratoxin were extracted, and the nanodrop UV-Vis spectrophotometer was used to verify the results (Table 1). Fig. 6 shows that the two treatment groups' baselines were stable, and the $5 \mathrm{~S}$ peak was normal. Furthermore, the purity, concentration, and integrity of the extracted RNA were consistent with subsequent analysis requirements.

Table 1. RNA test results for $G$. intermedia and A. ochraceus

\begin{tabular}{|c|c|c|c|c|c|c|c|}
\hline $\begin{array}{l}\text { Sample } \\
\text { name }\end{array}$ & $\begin{array}{l}\text { Concentration } \\
\text { (ug/uL) }\end{array}$ & $\begin{array}{l}\text { Volume } \\
\text { (uL) }\end{array}$ & $\begin{array}{l}\text { Total } \\
\text { (ug) }\end{array}$ & OD260/OD280 & OD260/OD230 & RIN & $28 S / 18 S$ \\
\hline $\begin{array}{l}\text { G. } \\
\text { intermedia- } \\
\text { treated }\end{array}$ & 1664 & 45 & 74.88 & 2.16 & 2.47 & 9.1 & 2.3 \\
\hline $\begin{array}{l}\text { G. } \\
\text { intermedia- } \\
\text { untreated }\end{array}$ & 1236 & 45 & 55.62 & 2.17 & 2.43 & 8.9 & 2.4 \\
\hline $\begin{array}{l}\text { A. } \\
\text { ochraceus- } \\
\text { treated }\end{array}$ & 1146 & 45 & 51.57 & 2.16 & 2.39 & 7.6 & 1.4 \\
\hline $\begin{array}{l}\text { A. } \\
\text { ochraceus- } \\
\text { untreated }\end{array}$ & 2052 & 45 & 92.34 & 2.14 & 2.38 & 6.8 & 1.5 \\
\hline
\end{tabular}

\subsubsection{The quality test results for the transcriptome sequencing for $G$. intermedia and $A$. ochraceus}

Table 2 shows the quality assessment of the $\mathrm{O}_{3}$-treated and untreated gibberellin and ochratoxin transcriptome. The sequencing data of the processed and untreated G. intermedia and A. ochraceus were good, meeting subsequent analysis requirements.

Table 2. Quality assessment of transcriptome sequencing data for G. intermedia and A. ochraceus 


\begin{tabular}{|lllllll|}
\hline Sample's name & $\begin{array}{l}\text { Raw reads } \\
(\mathrm{M})\end{array}$ & $\begin{array}{l}\text { Clean Reads } \\
(\mathrm{M})\end{array}$ & $\begin{array}{l}\text { Clean Bases } \\
(\mathrm{Gb})\end{array}$ & Q20(\%) & Q30(\%) & $\begin{array}{l}\text { GC } \\
(\%)\end{array}$ \\
\hline $\begin{array}{l}\text { G. intermedia-treated } \\
\text { G. intermedia- }\end{array}$ & 69.73 & 68.28 & 6.83 & 96.55 & 87.72 & 50.54 \\
untreated & 74.71 & 73.09 & 7.31 & 96.45 & 87.44 & 50.45 \\
\hline $\begin{array}{l}\text { A. ochraceus-treated } \\
\text { A. ochraceus- }\end{array}$ & 72.22 & 70.42 & 7.04 & 96.47 & 87.56 & 52.42 \\
\hline untreated & 69.73 & 68.19 & 6.82 & 96.50 & 87.64 & 52.31 \\
\hline
\end{tabular}

\subsubsection{The transcriptome assembly output data for G. intermedia and A. ochraceus}

Table 3 shows the results after aggregating the output data, indicating that the assembly quality of $G$. intermedia and $A$. ochraceus were good.

Table 3. Assembly result statistics for $G$. intermedia and A. ochraceus 


\begin{tabular}{|llll|}
\hline Strain name & Length Range & Transcript & UniGene \\
\hline \multirow{4}{*}{. intermedia } & $200-300$ & $6945(12.95 \%)$ & $3354(11.38 \%)$ \\
\cline { 2 - 4 } & $300-500$ & $5523(10.30 \%)$ & $2643(8.97 \%)$ \\
\hline $500-1000$ & $6420(11.97 \%)$ & $3182(10.79 \%)$ \\
\hline $1000-2000$ & $11717(21.84 \%)$ & $6308(21.40 \%)$ \\
\hline 2000-3000 & $8479(15.81 \%)$ & $4883(16.56 \%)$ \\
\hline >3000 & $14557(27.14 \%)$ & $9111(30.90 \%)$ \\
\hline Total Number & 53641 & 29481 \\
\hline Total Length & 116080340 & 69638845 \\
\hline N50 Length & 7030 & 3708 \\
\hline Mean Length & 4323 & 2362 \\
\hline 200-300 & $6877(9.03 \%)$ & $3309(8.22 \%)$ \\
\hline 300-500 & $6310(8.28 \%)$ & $2783(6.92 \%)$ \\
\hline 500-1000 & $7605(9.98 \%)$ & $3462(8.60 \%)$ \\
\hline 1000-2000 & $12578(16.51 \%)$ & $6265(15.57 \%)$ \\
\hline 2000-3000 & $11463(15.05 \%)$ & $6015(14.95 \%)$ \\
\hline >3000 & $31336(41.14 \%)$ & $18409(45.74 \%)$ \\
\hline Total Number & 76169 & 40243 \\
\hline Total Length & 247108484 & 145109459 \\
\hline N50 Length & 10644 & 5829 \\
\hline Mean Length & 6463 & 3605 \\
\hline
\end{tabular}

\subsubsection{The functional annotation of genes for $G$. intermedia and $A$. ochraceus}

The statistics for the gene annotation rate of the transcriptome sequencing data of $G$. intermedia and $A$. ochraceus are shown in Fig. 7. The overall annotation rate of the transcriptome sequencing data of $G$. intermedia and $A$. ochraceus reached respective levels as high as $99.53 \%$ and $89.89 \%$, providing a database for subsequent gene analysis.

\subsubsection{The effect of $\mathrm{O}_{3}$ on the gene expression of $G$. intermedia and $A$. ochraceus}

As shown in Fig. 8, the 03-treated and untreated groups' gene expression levels were compared to explore the effect of $\mathrm{O}_{3}$ treatment on the gene expression of gibberellin (ochratoxin) during the growth process. The results revealed the presence of 2754 (2378) differentially expressed genes ( $p$-value $<0.001$ and 
log2foldchange > 2) between the blank group and the treatment group, among which 1456 (1591) were upregulated and 1298 (787) were down-regulated.

\subsubsection{The $G O$ annotation of the differentially expressed genes for $G$. intermedia and A. ochraceus}

There were 16,13, and 8 annotation classifications for the biological process, cell composition, and molecular functionality, respectively (Fig. 9). According to the classification of differential gene GO annotations, the gene expression and regulation of Gibberella were influenced by the metabolic process, cell process, and localization of the biological process after $\mathrm{O}_{3}$ treatment. The gene expression and regulation of Gibberella were influenced by the cell, cell part, organelle, membrane, and membrane part of the cell composition. The gene expression and regulation of Gibberella were influenced by the catalytic activity, binding activity, transport activity, and transcriptional regulation activity of the molecular functions. The pathways with more differentially expressed genes include the metabolic process, cell process, localization, cell, cell part, membrane, membrane part, binding, and catalytic activity.

The pathways with more differentially expressed genes include the metabolic process, the cell process, localization, cell, cell part, membrane, membrane part, binding, and catalytic activity. Furthermore, there were 18,13 , and 10 annotation classifications for the differentially expressed genes in the biological process, cell composition, and molecular functionality, respectively. According to the classification of differential gene GO annotation, $\mathrm{O}_{3}$ treatment affects the gene expression and regulation of ochratoxin in the metabolic process, cell process, stress response, localization, cell component tissue or biogenesis, biological process regulation, and biological regulation of the biological process. The pathway affects the gene expression and regulation of ochratoxin in the cell, cell part, organelle, membrane, and membrane part. Furthermore, the pathway affects the gene expression and regulation of ochratoxin in the catalytic activity, binding, transport activity, and transcriptional regulation activity of the molecular functions. The pathways with more differentially expressed genes include the metabolism, cell process, cell, cell part, membrane, membrane part, binding, and catalytic activity.

\subsubsection{The significant enrichment of the differential genes of G. intermedia and A. ochraceus}

In order to find out the main function of $\mathrm{O}_{3}$ treatment on the inhibition of Gibberella and ochratoxin, go function significance enrichment analysis ( $p$-value $<0.05)$ was carried out for the differentially expressed genes of $\mathrm{O}_{3}$ treated and no $\mathrm{O}_{3}$ treated Gibberella and ochratoxin, and the results of significance enrichment were shown in Table 4. First, regarding cell composition, the nodes with significant enrichment in Gibberella were the membrane, the cell, the organelle, the macromolecule complex, and nucleoid, while the number of differentially expressed genes was 1, 2, 3, 2, and 1, respectively. The nodes with significant enrichment in the molecular functions were the catalytic activity, binding transport activity, signal sensor activity, and transcriptional regulation activity, while the number of differentially expressed genes was $19,13,6,1$, and 1 , respectively. There were $18,7,9,1$, and 5 differentially expressed genes in the cell process, biological regulation process, localization, stress response, and cell component tissue or biogenesis. Second, regarding the ochratoxin, the nodes with significant enrichment in the cell composition were the cells and organelles, while the number of differentially expressed genes was 9, 10, and 1, respectively. The nodes with significant 
enrichment in molecular functions were the catalytic activity, binding, signal sensor activity, and structural molecular activity, while the number of differentially expressed genes was $50,11,3$, and 1 , respectively. There were $48,16,8,4,1,1$, and 6 differentially expressed genes in the biological processes, including the cell process, biological regulation process, tissue or biogenesis of the cell components, metabolic process, and multiple biological processes stress response and localization.

Table 4. The significant enrichment of the GO function of the differentially expressed genes in G. intermedia and $A$. ochraceus by $\mathrm{O}_{3}$ 


\begin{tabular}{|c|c|c|c|c|}
\hline & GO function & Node & $\begin{array}{l}\text { Number of } \\
\text { up-regulated } \\
\text { genes }\end{array}$ & $\begin{array}{l}\text { Number of } \\
\text { down-regulated } \\
\text { genes }\end{array}$ \\
\hline \multicolumn{5}{|l|}{$\begin{array}{l}\text { Strain } \\
\text { name }\end{array}$} \\
\hline \multirow{15}{*}{$\begin{array}{l}\text { G. } \\
\text { intermedia }\end{array}$} & \multirow{5}{*}{$\begin{array}{l}\text { Cellular } \\
\text { component }\end{array}$} & Membrane part & 1 & 0 \\
\hline & & Cell & 1 & 1 \\
\hline & & Organelle part & 2 & 1 \\
\hline & & Macromolecular complex & 0 & 2 \\
\hline & & Nucleoid & 0 & 1 \\
\hline & \multirow{5}{*}{$\begin{array}{l}\text { Molecular } \\
\text { function }\end{array}$} & Catalytic activity & 9 & 10 \\
\hline & & Binding & 5 & 8 \\
\hline & & Transporter activity & 3 & 3 \\
\hline & & Signal transducer activity & 1 & 0 \\
\hline & & Transcription regulator activity & 0 & 1 \\
\hline & \multirow{5}{*}{$\begin{array}{l}\text { Biology } \\
\text { process }\end{array}$} & Biological regulation & 2 & 5 \\
\hline & & Cellular process & 8 & 10 \\
\hline & & Localization & 5 & 4 \\
\hline & & Response to stimulus & 1 & 0 \\
\hline & & $\begin{array}{l}\text { Cellular component organization or } \\
\text { biogenesis }\end{array}$ & 3 & 2 \\
\hline \multirow{10}{*}{$\begin{array}{l}\text { A. } \\
\text { ochraceus }\end{array}$} & \multirow{3}{*}{$\begin{array}{l}\text { Cellular } \\
\text { component }\end{array}$} & Cell & 7 & 2 \\
\hline & & Organelle part & 9 & 1 \\
\hline & & Cell part & 0 & 1 \\
\hline & \multirow{4}{*}{$\begin{array}{l}\text { Molecular } \\
\text { function }\end{array}$} & Catalytic activity & 33 & 17 \\
\hline & & Binding & 8 & 3 \\
\hline & & Signal transducer activity & 3 & 0 \\
\hline & & Structural molecule activity & 1 & 0 \\
\hline & \multirow{3}{*}{$\begin{array}{l}\text { Biology } \\
\text { process }\end{array}$} & Cellular process & 34 & 14 \\
\hline & & Biological regulation & 12 & 4 \\
\hline & & $\begin{array}{l}\text { Cellular component organization or } \\
\text { biogenesis }\end{array}$ & 6 & 2 \\
\hline
\end{tabular}




\begin{tabular}{lll|}
\hline Metabolic process & 4 & 0 \\
\hline Multi-organism process & 1 & 0 \\
\hline Response to stimulus & 1 & 0 \\
\hline Localization & 2 & 4 \\
\hline
\end{tabular}

\subsubsection{The annotation of the differentially expressed gene KEGG of $G$. intermedia and A. ochraceus}

The annotation classification map of the KEGG pathway of the $\mathrm{O}_{3}$-treated and untreated gibberellins is shown in Fig. 10(a). Here, 2503 differentially expressed genes were annotated into the KEGG database, 22 metabolic pathways were annotated by the KEGG pathway of which two metabolic pathways belonged to the cell process, two to the environmental information process, and four to the genetic information process, while 13 were metabolic processes, and one denoted the organic system. There were 176 differential gene annotations to the transport and catabolism pathway, 117 to the cell growth and death pathway, 118 to the signal transduction pathway, 64 to the gene transcription pathway, and 167 to the gene transcription pathway during environmental information processing. In the translation process, 171 differential gene annotations were included in the gene folding, classification, and degradation pathways, 77 in the DNA replication and repair pathways, 237 in the carbohydrate metabolism pathway, and 552 in the overall overview pathway.

The annotation classification diagram of the KEGG pathway denoting the differential expression genes between the $\mathrm{O}_{3}$-treated and the untreated Aspergillus ochre is shown in Fig. 10(b). Here, 1934 differentially expressed genes were annotated into KEGG by Aspergillus ochre, including 22 metabolic pathways in total, of which two were due to the cellular process, two due to environmental information processing, four due to genetic information processing, 12 due to the metabolic process, and two due to the organic system. Furthermore, there were 156 differential gene annotations during the process of cell transportation and catabolism, 40 during the process of cell growth and death, 76 during the process of environmental information processing, 35 during the process of genetic information processing, and 107 during the process of gene transcription. In the process of translation, there were 80 differential gene annotations into the gene folding, classification, and degradation pathways, 30 into DNA replication and repair pathways, 229 into the carbohydrate metabolism pathway, 496 into the whole body overview pathway, 182 into the amino acid metabolism pathway, and 123 into the lipid metabolism pathway.

\subsubsection{The enrichment of allogeneic KEGG for $G$. intermedia and $A$. ochraceus}

As shown in Table 5, the statistics regarding the significant KEGG enrichment (p-value $<0.05$ ) of the differentially expressed genes between the $\mathrm{O}_{3}$-treated and untreated Gibberella and ochratoxin were studied, and the metabolic process of the genes involved in the inhibition of Gibberella and ochratoxin growth by $\mathrm{O}_{3}$ was explored. The results indicated that $\mathrm{O}_{3}$ affects the growth of Gibberella via the KEGG pathway process mentioned above, and even causes its death. In addition, $\mathrm{O}_{3}$ mainly affects the growth and death of ochratoxin by impacting its amino acids, overall overview, and lipid metabolism.

Table 5. The significant enrichment of differential genes in KEGG for G. intermedia and A. ochraceus 


\begin{tabular}{|c|c|c|c|}
\hline $\begin{array}{l}\text { Strain } \\
\text { name }\end{array}$ & KEGG pathway & $\begin{array}{l}\text { Number of differentially expressed } \\
\text { genes }\end{array}$ & $\begin{array}{l}\text { Rich } \\
\text { Ratio }\end{array}$ \\
\hline \multirow{10}{*}{$\begin{array}{l}\text { G. } \\
\text { intermedia }\end{array}$} & Amino acid metabolism & 2 & 0.2122 \\
\hline & $\begin{array}{l}\text { Biosynthesis of other secondary } \\
\text { metabolites }\end{array}$ & 2 & 0.2894 \\
\hline & Carbohydrate metabolism & 2 & 0.2243 \\
\hline & Cell growth and death & 1 & 0.0974 \\
\hline & Lipid metabolism & 3 & 0.4321 \\
\hline & Membrane transport & 1 & 0.0957 \\
\hline & Metabolism of cofactors and vitamins & 5 & 0.5984 \\
\hline & Metabolism of other amino acids & 1 & 0.1103 \\
\hline & $\begin{array}{l}\text { Metabolism of terpenoids and } \\
\text { polyketides }\end{array}$ & 1 & 0.1875 \\
\hline & Transcription & 1 & 0.0920 \\
\hline \multirow{13}{*}{$\begin{array}{l}\text { A. } \\
\text { ochraceus }\end{array}$} & Aging & 1 & 0.0852 \\
\hline & Amino acid metabolism & 5 & 0.3015 \\
\hline & $\begin{array}{l}\text { Biosynthesis of other secondary } \\
\text { metabolites }\end{array}$ & 1 & 0.1143 \\
\hline & Carbohydrate metabolism & 3 & 0.2313 \\
\hline & Energy metabolism & 3 & 0.1887 \\
\hline & Folding, sorting, and degradation & 2 & 0.1307 \\
\hline & Global and overview maps & 6 & 0.3306 \\
\hline & Glycan biosynthesis and metabolism & 2 & 0.1838 \\
\hline & Lipid metabolism & 6 & 0.5139 \\
\hline & Metabolism of cofactors and vitamins & 3 & 0.2906 \\
\hline & Metabolism of other amino acids & 3 & 0.2067 \\
\hline & Nucleotide metabolism & 1 & 0.0358 \\
\hline & Transport and catabolism & 1 & 0.0345 \\
\hline
\end{tabular}

\section{Discussion}


The freshly-peeled garlic inoculated with G. intermedia and A. ochraceus were treated with different ozone concentration, time, temperature and humidity in vivo to explore the effect of ozone on the performance of rot-causing mold. The effects of different ozone treatment conditions were studied by measuring theTNC, TNMY, incidence, spot diameter and spot depth of freshly-peeled garlic. For G. intermedia and A. ochraceus, it has better bactericidal and inhibitory effect under the conditions of ozone treatment concentration $6 \mathrm{ppm}$, ozone treatment time $15 \mathrm{~min}$, ozone treatment temperature $20^{\circ} \mathrm{C}$ and ozone treatment humidity $90 \%$. The experimental results showed that ozone concentration, ozone treatment time and humidity had significant effects on the indexes of freshly-peeled garlic, but there was no significant difference between ozone treatment temperature and ozone treatment temperature. Gabler,Smilanick, Mansour, and Karaca (2010) pointed out that, after 5.4, 10.7 and $21.4 \mathrm{mg} \mathrm{L}-1$ gaseous ozone treatments for up to $2 \mathrm{~h}$, postharvest gray mold was reduced by approximately $50 \%$ after $7 \mathrm{~d}$ at $15^{\circ} \mathrm{C}$ storage on table grapes. Yeoh et al. (2014) studied the effects of ozone on antioxidant activity and main microbial community of fresh-cut papaya. The results showed that $9.2 \mu \mathrm{I} / \mathrm{L}$ ozone treatment of $20 \mathrm{~min}$ could achieve better fresh-keeping effect. Wang et al (2010) study that the high concentration of gaseous ozone significantly reduced the number of salmonella in tomatoes.

The primary target of ozone is the cell surface where degradation of unsaturated lipids of the cell envelope occurs, followed by the leakage of cellular contents and bacterialcells lyses (Komanapalli \& Lau, 1996). Komanapalli and Lau(1996) further asserted that ozone could infiltrate the microorganisms to oxidize inner contents such as proteins, nucleic acids and enzymes.

The differences of transcriptome sequencing and expression genes of G. intermedia and A. ochraceus treated with and without ozone treatment were analyzed. For G. intermedia, $68.28 \mathrm{~m}$ and $73.09 \mathrm{~m}$ Clean reads were obtained by sequencing in the treated and untreated groups, and a total of 29481 Unigenes were obtained after assembly. The annotation rates in NR, NT, Swissprot, KEGG, KOG, Pfam and GO were 89.71\%, $97.58 \%, 61.72 \%, 64.59 \%, 54.47 \%, 70.27 \%$ and $27.25 \%$, respectively. A total of 2754 differentially expressed genes were obtained, including 1456 up-regulated genes and 1298 down-regulated genes. According to GO analysis, differentially expressed genes were significantly enriched to catalytic activity, binding transport activity, cell process and biological regulation process. According to KEGG analysis, ozone affected the G. intermedia of amino acids, carbohydrates, lipids, cofactors and vitamins of Fusarium oxysporum.

For A. ochraceus, $70.42 \mathrm{M}$ and $68.19 \mathrm{M}$ Clean reads were obtained in treated and untreated groups, respectively, and a total of 40243 Unigenes were obtained after assembly. The annotation rates in NR, NT, Swissprot, KEGG, KOG, Pfam and GO were 87.95\%, 59.06\%, 70.68\%, 73.01\%, 65.09\%, 76.63\% and $54.72 \%$, respectively. A total of 2378 differentially expressed genes were obtained, including 1591 up-regulated genes and 787 down-regulated genes. According to GO analysis, differentially expressed genes were significantly enriched in cells, organelles, catalytic activity, binding process, cellular process and biological regulation process. From the KEGG analysis, ozone mainly affected the A. ochraceus, overall overview and lipid metabolism of Aspergillus ochre. The results showed that the transcriptome sequencing and difference analysis of treated and untreated rot-causing molds were carried out to explore the inhibition mechanism of ozone on freshly-peeled garlic rot-causing molds, which provides a theoretical basis for further study and ozone preservation of fresh-peeled garlic. 
In this study, it was found that ozone treatment could significantly reduce the total number of colonies, molds and yeasts, incidence, spot diameter and spot depth of freshly peeled garlic during storage, and achieved a better germicidal and inhibitory effect. So far, the germicidal effect of ozone on fruits and vegetables has been applied to broccoli, pepper, strawberry, guava, papaya and other fruits and vegetables (Nur aida MP et al ,2011), as well as fresh-cut lotus root slices, fresh-cut pineapple, fresh-cut kiwifruit and other fresh-cut fruits and vegetables (Tzortzakis $\mathrm{N}$ et al, 2007; Karaca $\mathrm{H}$ et al, 2014). It reacts with the components of microbial cells on the surface of fruits and vegetables, destroys the components of the membrane, causes metabolic imbalance, further destroys the tissue inside the cell membrane, and produces irreversible destruction, thus killing microorganisms. The results of the study will provide a theoretical basis for the further study of the bacteriostatic mechanism of ozone, and provide a certain theoretical basis and technical guidance for the application of ozone in the processing industry and commercial development of freshly-peeled garlic. it has guiding significance for the industrialization of ozone fresh-keeping processing of fresh-peeled garlic.

\section{Abbreviations}

\begin{tabular}{|ll|}
\hline The total number of colonies & TNC \\
\hline The total number of mold and yeast & TNMY \\
\hline The colony-forming units & CFU \\
\hline phosphate buffer saline & PBS \\
\hline Kyoto Encyclopedia of Genes and Genomes & KEGG \\
\hline Gene Ontology & GO \\
\hline nonredundant protein & NR \\
\hline Nonredundant nucleic acid & NT \\
\hline Karyotic Orthologous Groups & KOG \\
\hline
\end{tabular}

\section{Declarations}

\section{Acknowledgements}

We are grateful for the funding support from the Science and technology support program of Sichuan [2019YFN0174, 2018NZ0090, 2019NZZJ0028 and 2017NFP0030], Science and technology support program of Yibin [2018ZSF002], Chengdu Science and Technology Project- key research and development program [2019-YF05-00628-SN囚2019-YF05-00190-SN], Innovation Team Construction Program of Sichuan Education Department [15TD0017], and Provincial Innovation and Entrepreneurship Training Program for College Students of Xihua University [201710623037].

\section{Ethics approval and consent to participate}


Not applicable' for that section

\section{Consent for publication}

All authors have approved this manuscript, and confirmed that this research has not been publisbed before, nor is it considered for publication elsewhere.

\section{Availability of data and materials}

All data about this research are in this manuscript.

\section{Competing interests}

All authors declare that they have no conflicts of interest.

\section{Funding}

This work is supported by the Science and technology support program of Sichuan [2019YFN0174, 2018NZ0090, 2019NZZJ0028 and 2017NFP0030], Science and technology support program of Yibin [2018ZSF002], Chengdu Science and Technology Project- key research and development program [2019YF05-00628-SN区2019-YF05-00190-SN], Innovation Team Construction Program of Sichuan Education Department [15TD0017], and Provincial Innovation and Entrepreneurship Training Program for College Students of Xihua University [201710623037].

\section{Authors' contributions All authors}

The study was designed by YM, YGX, QLX and XCL;LC, PY, JT,XMW and HY carried out the research; PY, XLL and LX analyzed the data; PY,XFB and HY cllted information;PYand LC prepared the manuscript.authors have made corresponding contributions to this research work.

\section{Author details}

a Key Laboratory of Grain and Oil Processing and Food Safety of Sichuan Province, College of Food and Bioengineering, Xihua University, Chengdu, 610039, China

b Key Laboratory of Food Non-Thermal Technology, Engineering Technology Research Center of Food NonThermal, Yibin Xihua University Research Institute, Yibin, 644004, China

c Leshan normal university of Sichuan Province, Leshan, 614000, China

\section{References}

1.Biljana B, Neda M D, Isidora S, Anackov G, Ruzica I (2008) Phenolics as antioxidants in garlic (Allium sativum L., Alliaceae). Food Chemistry: 111(4), 925-929 
2.Martins N, Petropoulos S, Ferreira, ICFR (2016) Chemical composition and bioactive compounds of garlic (Allium sativum L.) as affected by pre- and post-harvest conditions: A review. Food chemistry: 211, 41-50

3.Cui N W, Meng Y W, Yin X D, Zhi H C Huan W M (2016) Effect of plant age and vernalization on bolting, plant growth and enzyme activity of garlic (Allium sativum L.). Scientia Horticulturae: 201, 295-305

4.Rana S V, Pal R, Vaiphei K, Sharma S K, Ola R P (2011) Garlic in health and disease. Nutrition research reviews: 24(1), 60-71

5.Suman S, Kirtiraj K, Gaikwad, Youn S L (2019) Development and application of a pyrogallic acid-based oxygen scavenging packaging system for shelf life extension of peeled garlic. Scientia Horticulturae: 256, 108548

6.Kalliopi M, Efstathia Kogkaki, Michael S, Naresh M (2014) Efficacy of gaseous ozone treatment on spore germination, growth and fumonisin production by Fusarium verticillioides in vitro and in situ in maize. Journal of Stored Products Research: 59, 178-184

7.Tzortzakis N, Singleton I, Barnes J (2007) Deployment of low-level ozone-enrichment for the preservation of chilled fresh produce. Postharvest Biology and Technology:43(2), 261-270

8.De V G A, Stalter D, Gernjak W G, Weinberg H S, Keller J, Farré M J (2015) Towards reducing DBP formation potential of drinking water by favouring direct ozone over hydroxyl radical reactions during ozonation. Water research: $87,49-58$

9.Qi L J, Li Y L, Luo X H, Wang R, Zheng R, Wang L, Li Y F, Yang D, Fang W M, Chen Z X (2016) Detoxification of zearalenone and ochratoxin $A$ by ozone and quality evaluation of ozonised corn. Food additives \& contaminants. Part A, Chemistry, analysis, control, exposure \& risk assessment: 33(11), 1700-1710

10.Sarig P, Zahavi T, Zutkhi Y, Yannai S, Lisker N, Ben-Arie R (1996) Ozone for control of post-harvest decay of table grapes caused by Rhizopus stolonifer. Physiological and Molecular Plant Pathology: 48(6), 403-415

11.Freitas-Silva O, Venancio A (2010) Ozone applications to prevent and degrade mycotoxins: a review. Drug Metabolism Reviews: 42(4), 612-620

12.Ong M K, Ali A (2015) Antifungal action of ozone against Colletotrichum gloeosporioides and control of papaya anthracnose. Postharvest Biology and Technology: 100, 113-119

13.Karaca H, Velioglu Y S, Nas S (2010) Mycotoxins: contamination of dried fruits and degradation by ozone. Toxin Reviews: 29(2), 51-59

14.Brodowska A J, Nowak A, Smigielski K (2018) Ozone in the food industry: Principles of ozone treatment, mechanisms of action, and applications: An overview. Critical Reviews In Food Science And Nutrition: 58(13), 2176-2201 
15.Cataldo F (2008) Ozone decomposition of Patulin - A micotoxin and food contaminant. Ozone-Science \& Engineering: 30(3), 197-201

16.Cho J M, Hyun J J, Lee K H (2009) Effect of Ozone Treatment for Safety Improvement of Fresh Vegetable Juice. Journal of the Korean Society of Food Science and Nutrition: 38(5), 612-617

17.Parish M E, Beuchat L R, Suslow T V, Harris L J, Garrett E H, Farber J N, Busta F F (2003) Methods to Reduce/Eliminate Pathogens from Fresh and Fresh-Cut Produce. Comprehensive Reviews in Food Science and Food Safety: 2(s1), 161-173

18.Ioannis S Minas, George S Karaoglanidis, George A Manganaris, Miltiadis Vasilakakis (2010) Effect of ozone application during cold storage of kiwifruit on the development of stem-end rot caused by Botrytis cinerea. Postharvest Biology and Technology: 58(3), 203-210

19.Moscoso-Ramírez P A, Palou L (2014) Effect of ethylene degreening on the development of postharvest penicillium molds and fruit quality of early season citrus fruit. Postharvest Biology and Technology: 91, 1-8

20.Akshata R Salve, Kakoli P, Shalini S A (2019) Comparative assessment of high-intensity ultrasound and hydrodynamic cavitation processing on physico-chemical properties and microbial inactivation of peanut milk. Ultrasonics Sonochemistry:59, 104728

21.Chen C K, Zhang H J, Zhang X J, Dong C H, Xue W T, Xu W T (2020) The effect of different doses of ozone treatments on the postharvest quality and biodiversity of cantaloupes. Postharvest Biology and Technology:163, 111-124

22.Showkat A L, Sathya R, Mubarak A D, Hemalatha S, Sang-Yul L (2019) An investigation on the sterilization of berry fruit using ozone: An option to preservation and long-term storage. Biocatalysis and Agricultural Biotechnology: 20, 101212

23.Glowacz M, Rees D (2016) Exposure to ozone reduces postharvest quality loss in red and green chilli peppers. Food chemistry: 210, 305-310

24.Gabler, F. M., Smilanick, J. L., Mansour, M. F., \& Karaca, H. (2010). Influence of fumigation with high concentrations of ozone gas on postharvest gray mold and fungicide residues on table grapes. Postharvest Biology and Technology, 55, 85-90.

25.Wei KY, Ali A, Forney CF. Effects of Ozone on Major Antioxidants and Microbial Populations of Fresh-cut Papaya[J]. Postharvest Biology \& Technology, 2014, 89(50): 56-58.

26.Lin Wang,Xuetong Fan,Kimberly Sokorai,Joseph Sites.Quality deterioration of grape tomato fruit during storage after treatments with gaseous ozone at conditions that significantly reduced populations of Salmonella on stem scar and smooth surface[J].Food Control,2019,103(103):.

27.Komanapalli, I., \& Lau, B. (1996). Ozone-induced damage of Escherichia coli K-12.Applied Microbiology and Biotechnology, 46, 610-614. 

'josapine' Pineapple During Storage[J]. Acta Horticulturae, 2011, 902(902): 487-492.

29.Karaca H, Velioglu YS. Effects of Ozone Treatments on Microbial Quality and Some Chemical Properties of Lettuce, Spinach, and Parsley[J]. Postharvest Biology \& Technology, 2014, 88(2): 46-53.

\section{Figures}

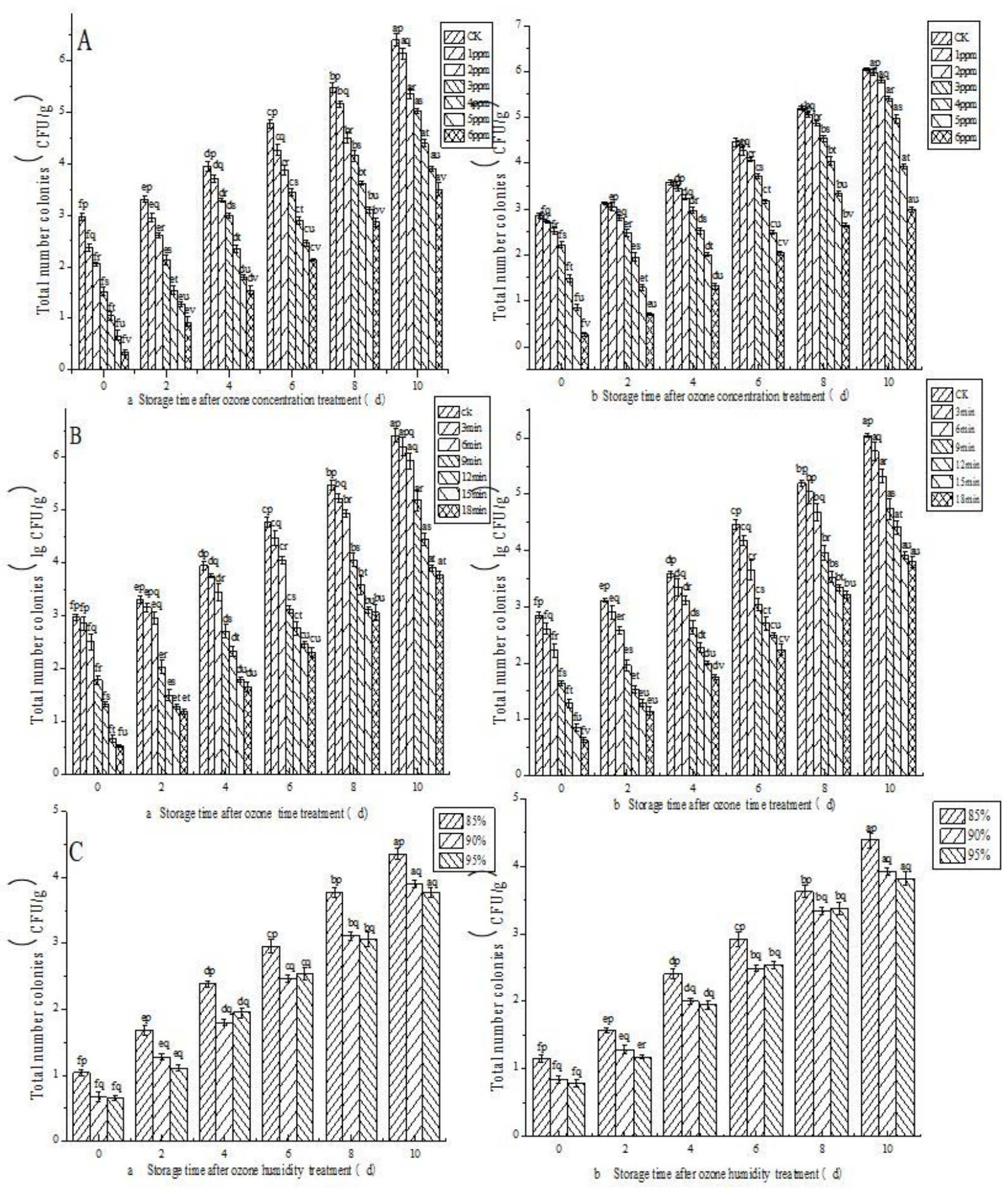


Figure 1

The effect of different 03 treatment conditions (A: concentrations; $B$ : times; $C$ : humidity) on the TNC in freshly-peeled garlic (a: G. intermedia; b: A. ochraceus)

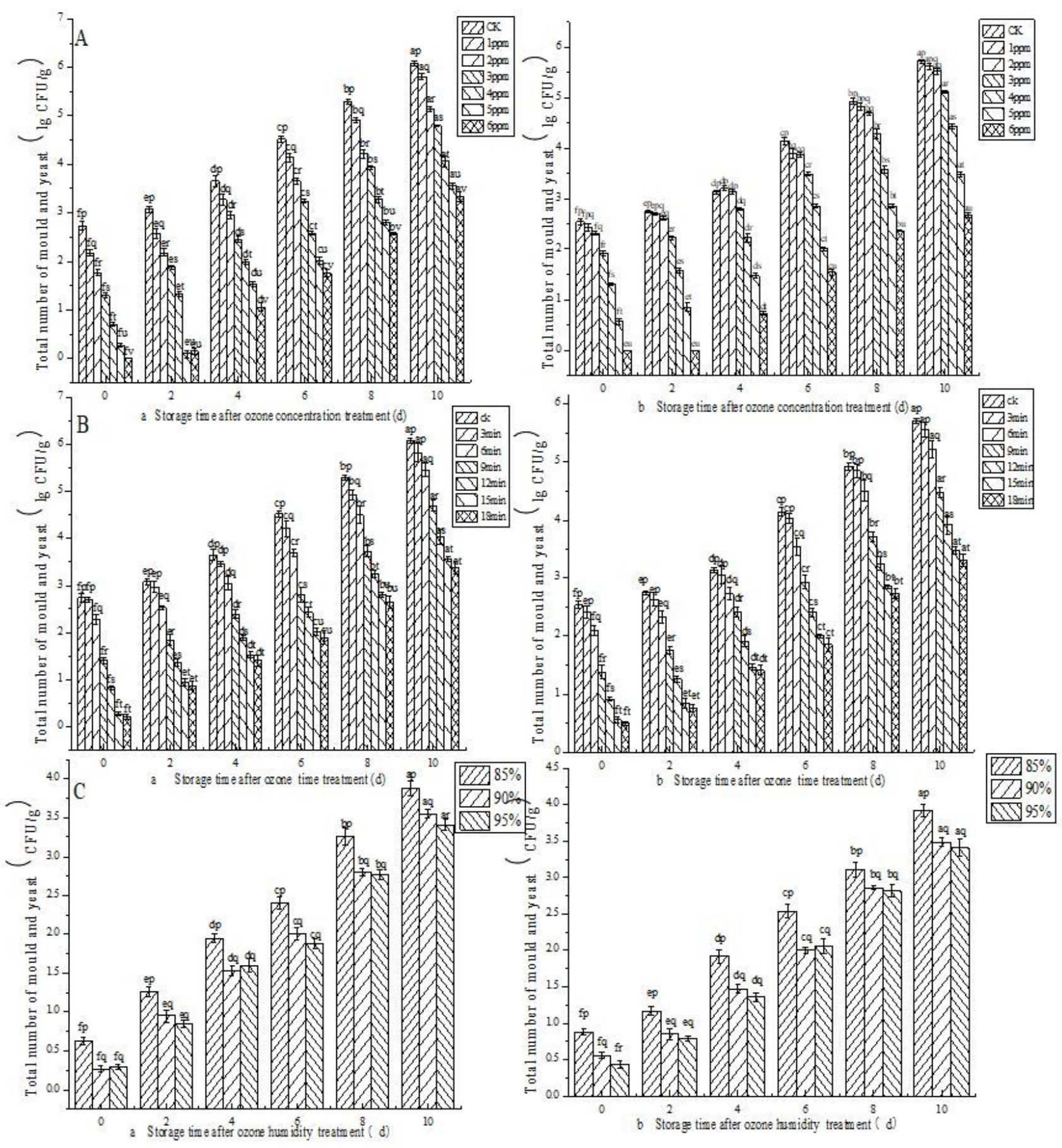

Figure 2

The effect of different 03 treatment conditions (A: concentrations; B: times; C: humidity) on the total number of Pythium and yeast in the freshly-peeled garlic (a: G. intermedia; b: A. ochraceus) 

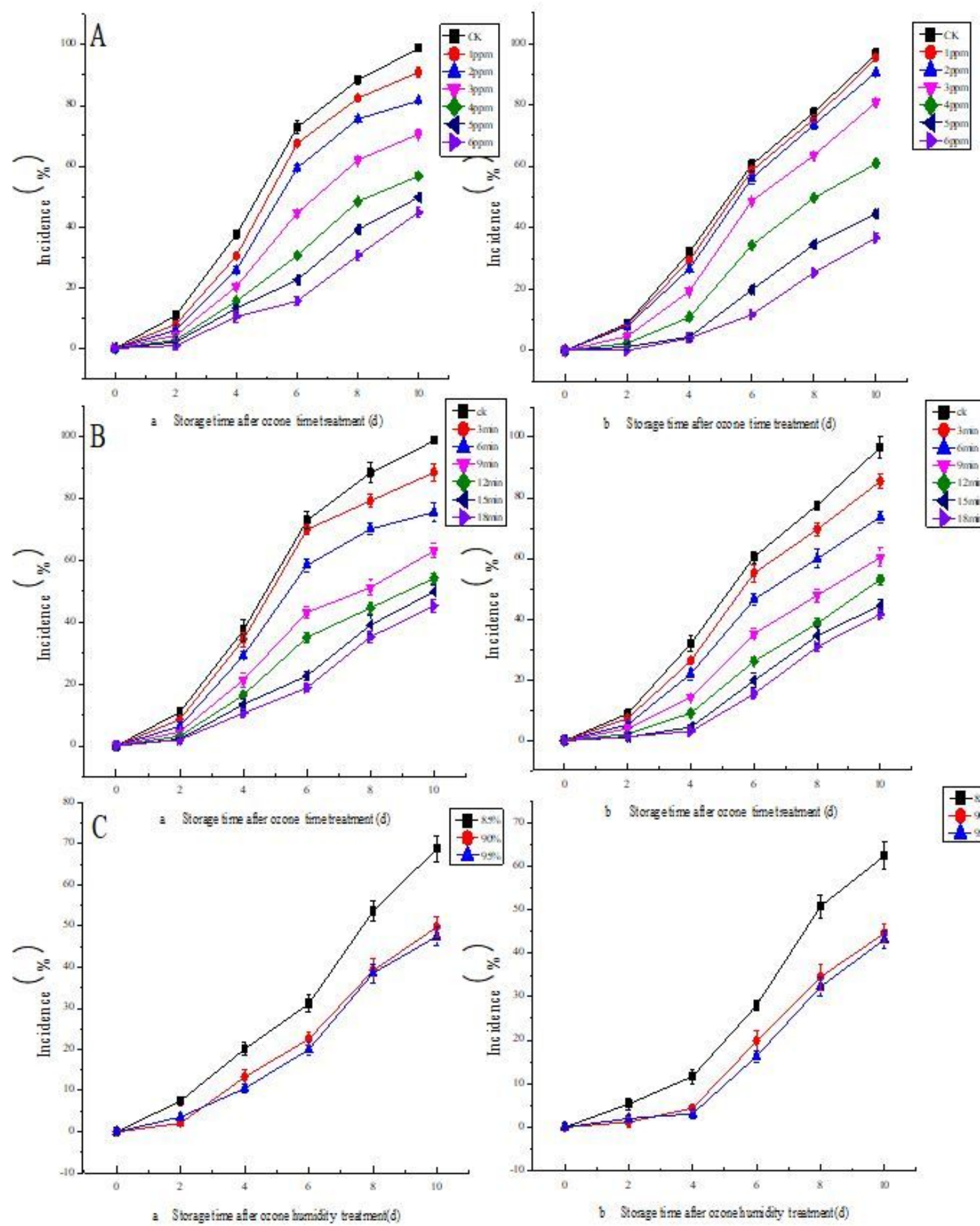

\section{Figure 3}

The effect of different 03 treatment conditions (A: concentrations; B: times; $\mathrm{C}$ : humidity) on the incidence of the freshly-peeled garlic (a: G.intermedia; b: A. ochraceus) 

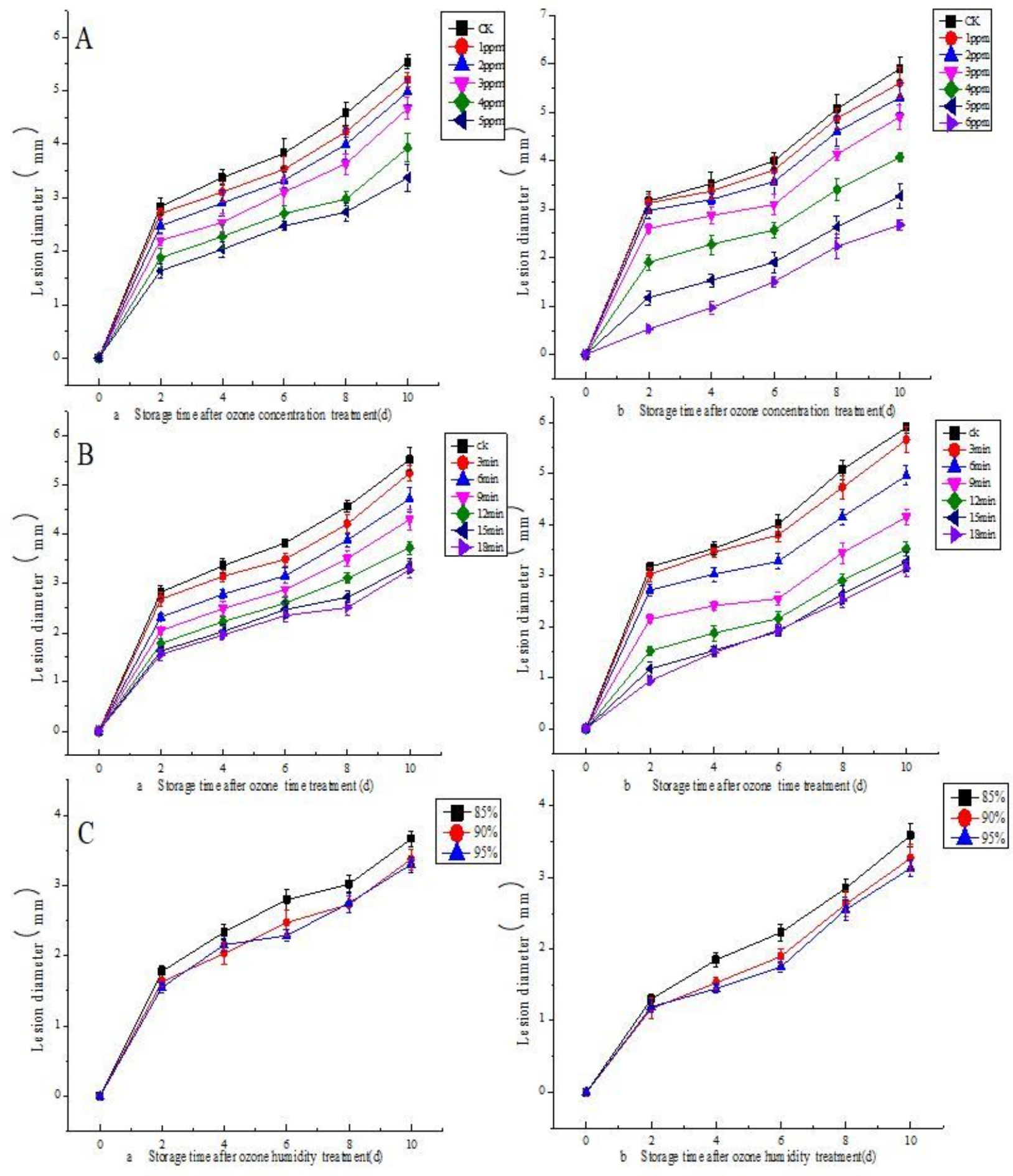

Figure 4

The effect of different $\mathrm{O} 3$ treatment conditions (A: concentrations; $\mathrm{B}$ : times; $\mathrm{C}$ : humidity) on the lesion diameter of the freshly-peeled garlic (a: G. intermedia; b: A. ochraceus) 

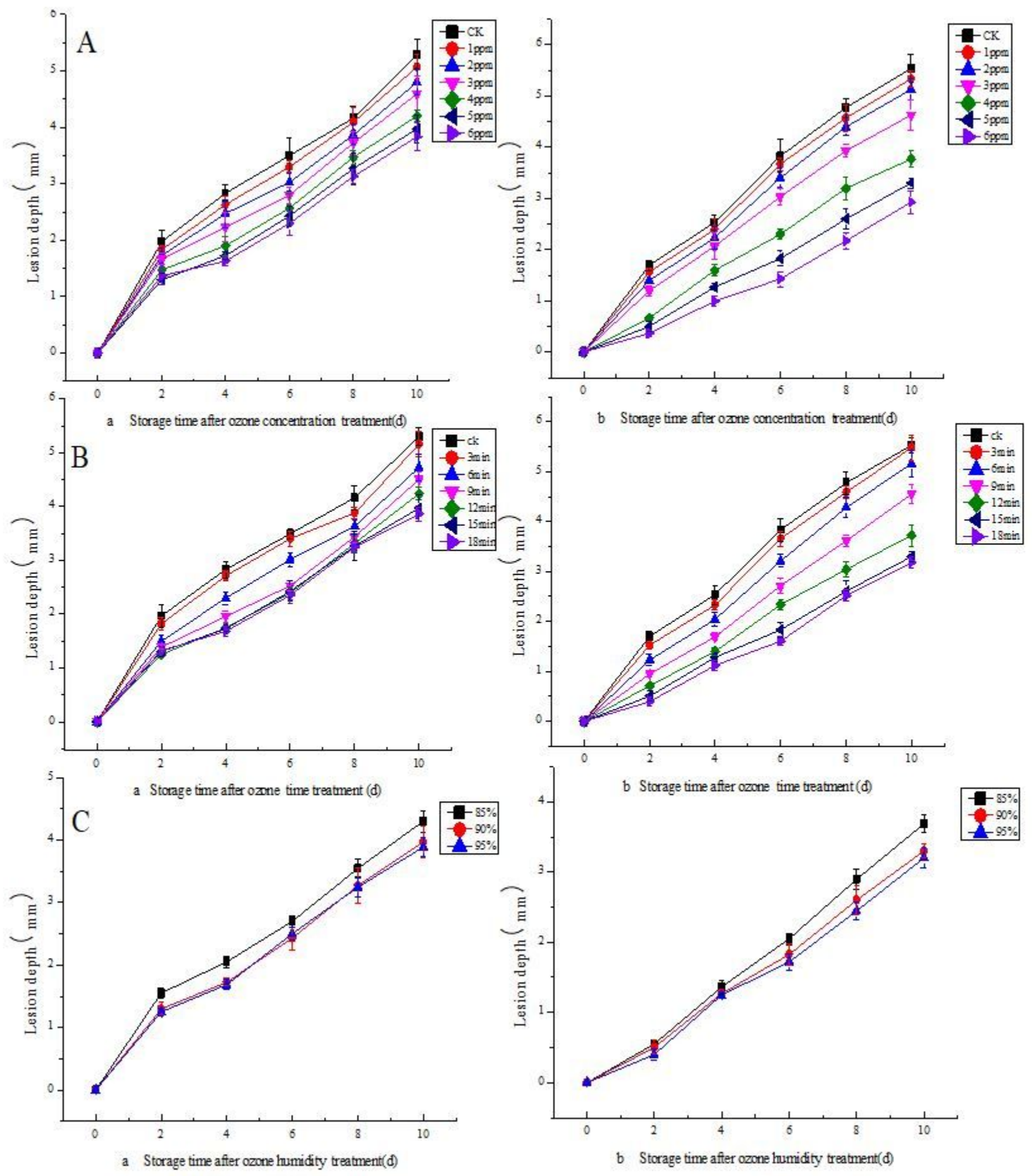

Figure 5

The effect of different 03 treatment conditions (A: concentrations; B: times; C: humidity) on the lesion depth of the freshly-peeled garlic (a: G. intermedia; b: A. ochraceus) 


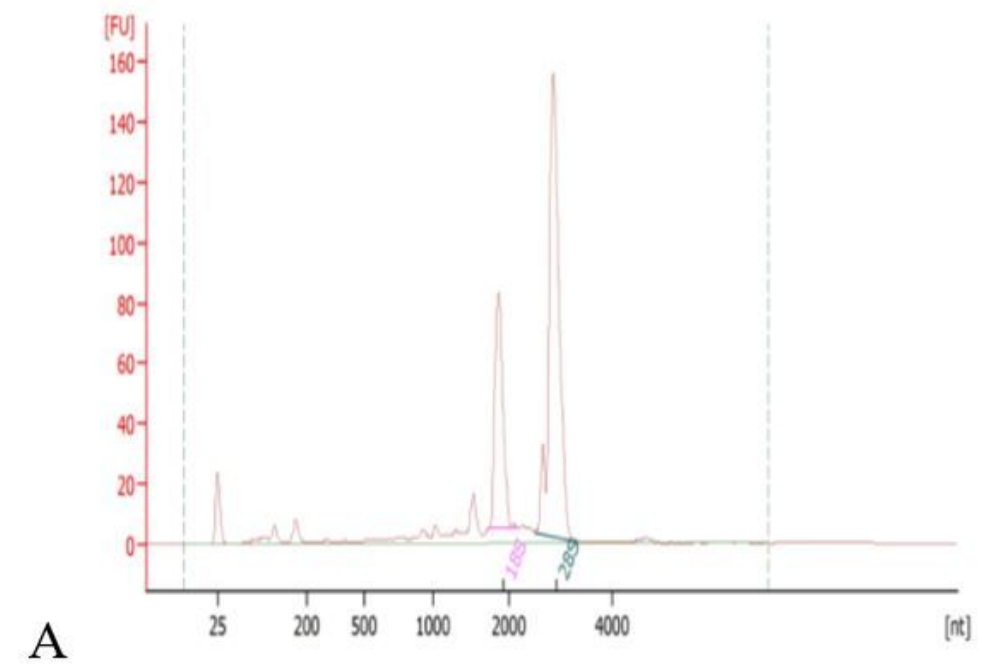

(a)

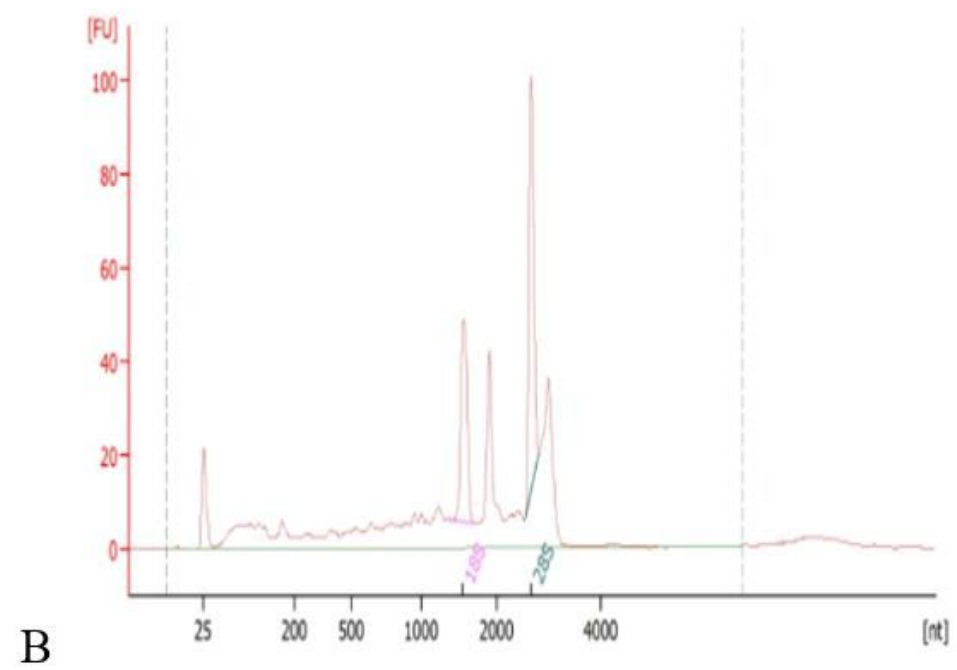

(a)

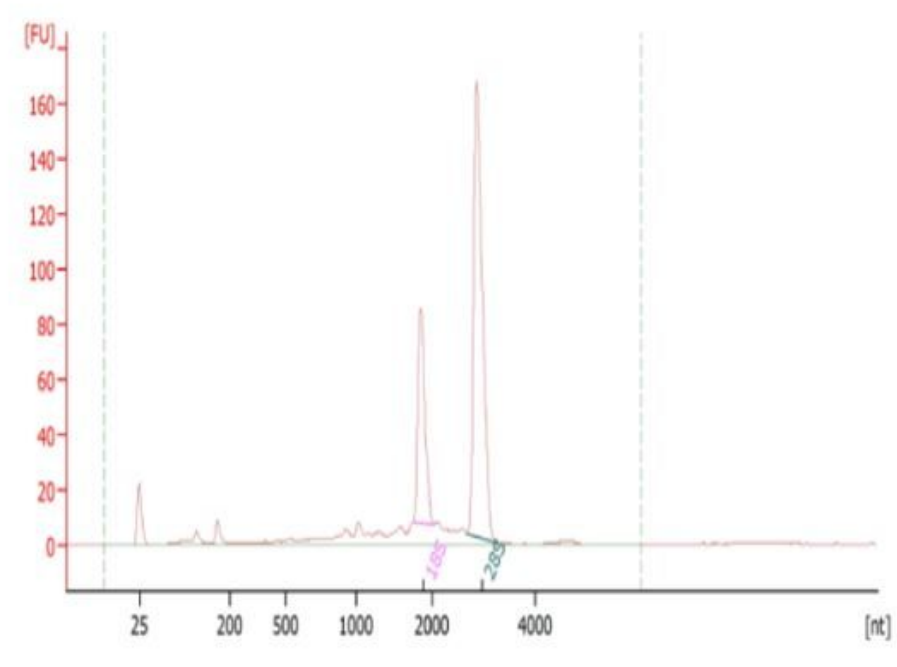

(b)

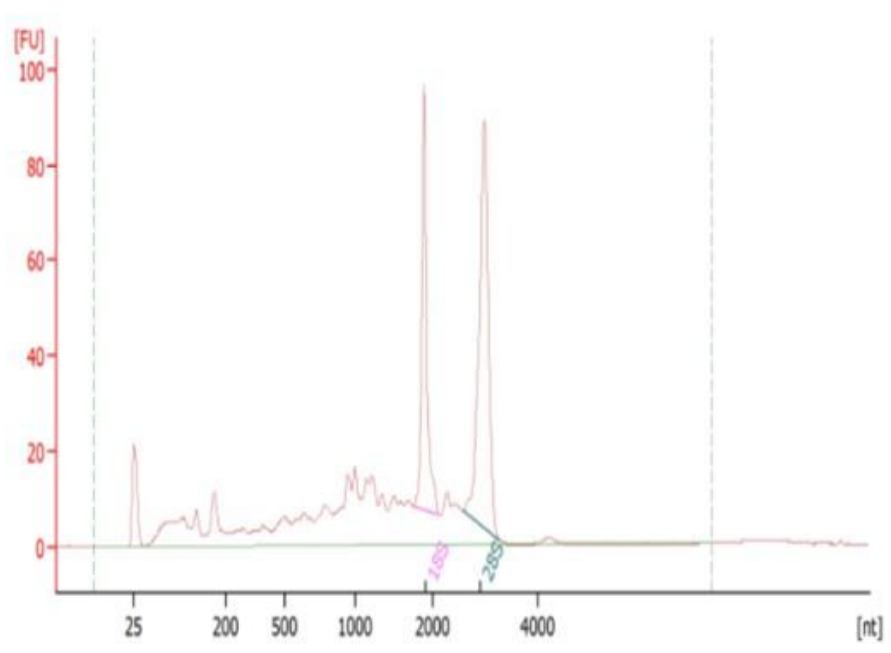

(b)

\section{Figure 6}

RNA Agilent 2100 detection results for G. intermedia and A. ochraceus (A: G. intermedia; B: A. ochraceus; a. Treatment; b. Untreated) 


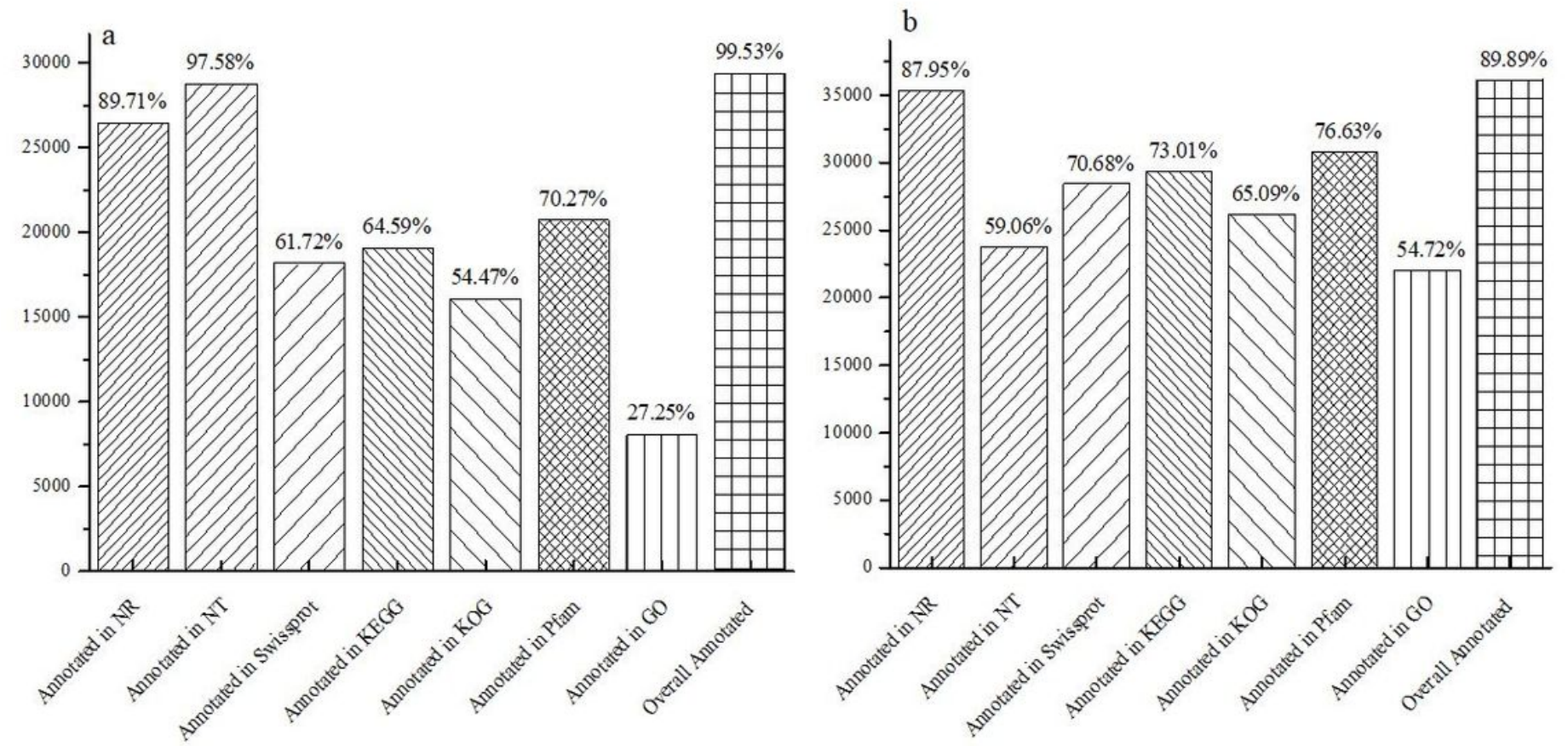

Figure 7

The gene annotation rate statistics for (a) G. intermedia and (b) A. ochraceus

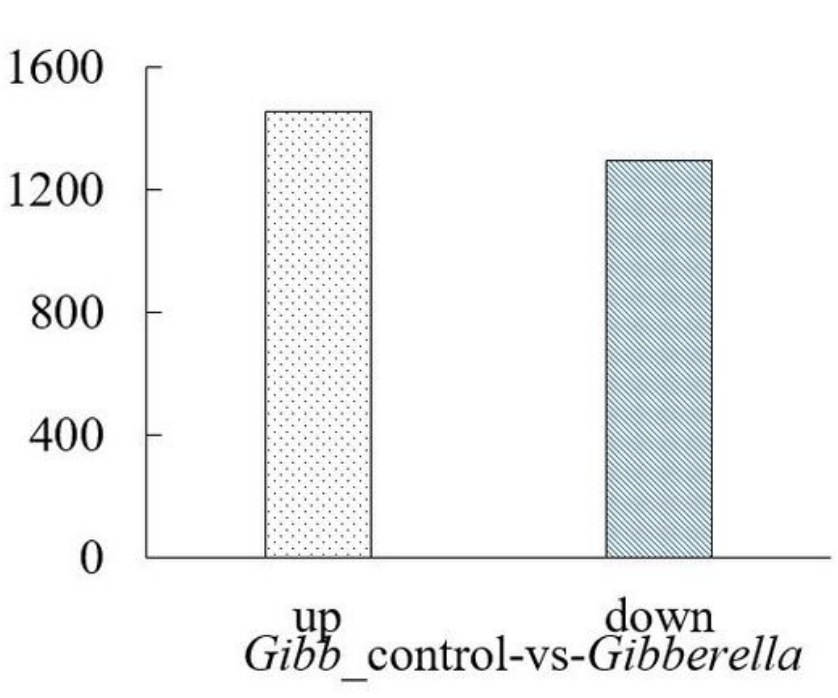

(a)

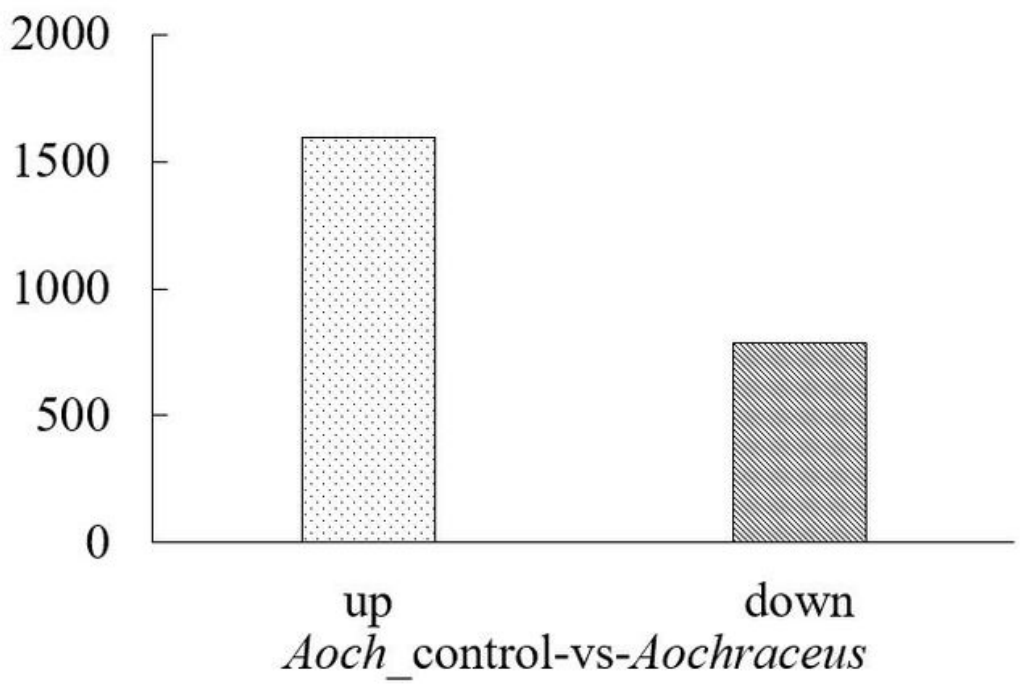

(b)

\section{Figure 8}

The numerical statistics of the differentially expressed genes for (a) G. intermedia and (b) A. ochraceus 


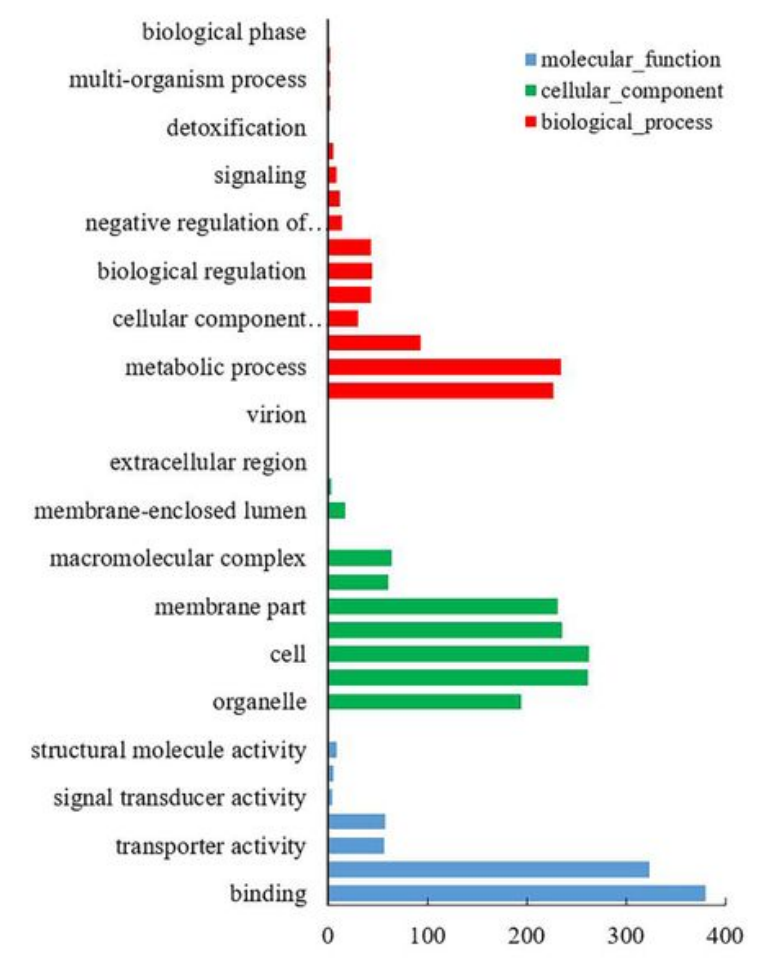

(a)

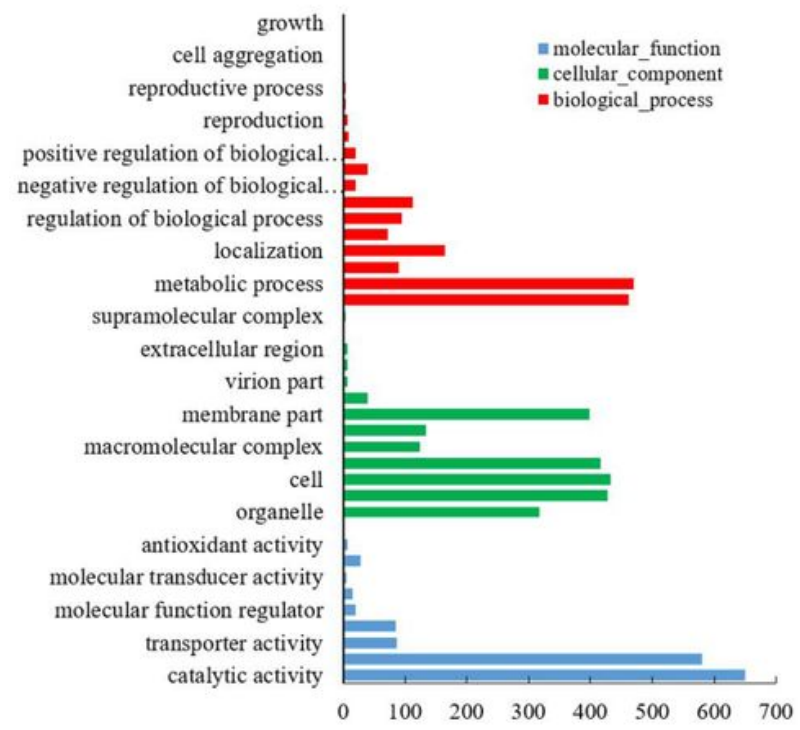

(b)

\section{Figure 9}

The GO annotated statistical map of the differentially expressed genes for (a) G. intermedia and (b) A. ochraceus 


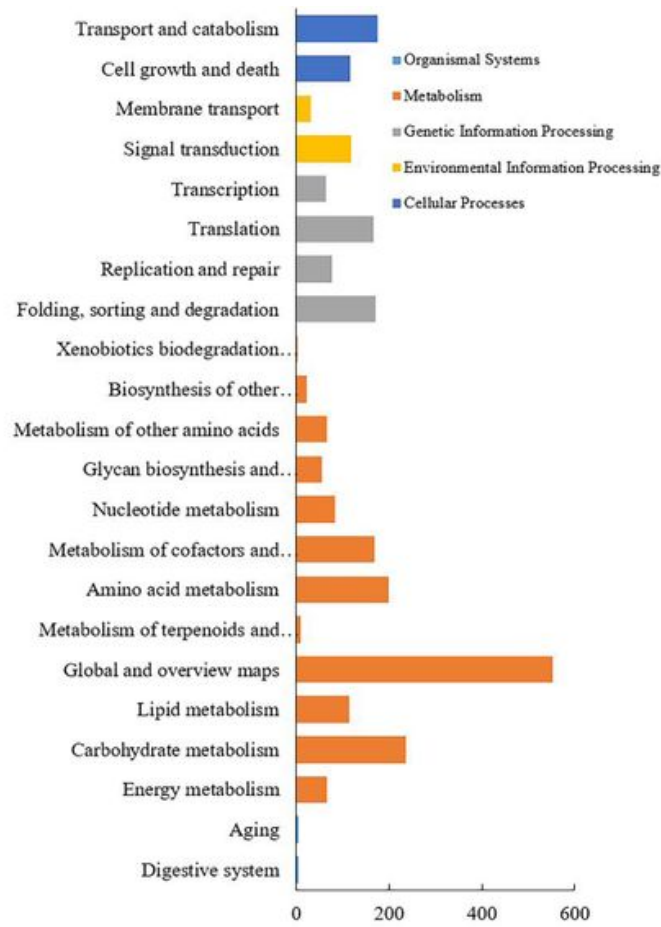

(a)

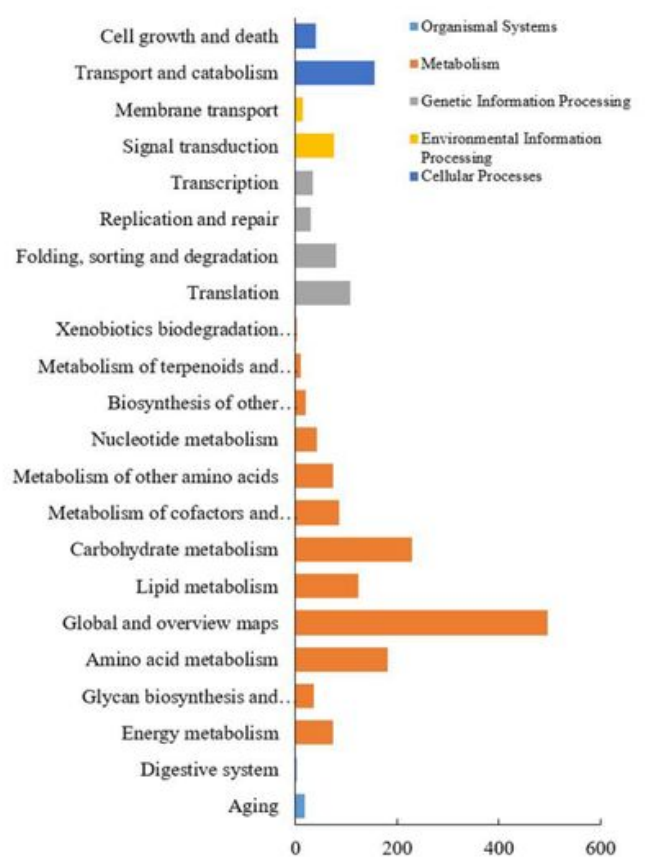

(b)

\section{Figure 10}

The differential expression gene KEGG annotation classification for (a) G. intermedia and (b) A. ochraceus 